J. Dairy Sci. 99:8733-8745

http://dx.doi.org/10.3168/jds.2016-11570

(C) American Dairy Science Association ${ }^{\circledR}, 2016$.

\title{
Characteristics of dairy cows with a greater or lower risk of subacute ruminal acidosis: Volatile fatty acid absorption, rumen digestion, and expression of genes in rumen epithelial cells
}

\author{
X. Gao and M. Oba ${ }^{1}$ \\ Department of Agricultural, Food and Nutritional Science, University of Alberta, Edmonton, Alberta, Canada, T6G 2P5
}

\begin{abstract}
The objective of this study was to examine whether lactating dairy cows with a greater or lower risk of subacute ruminal acidosis (SARA) have differences in volatile fatty acid (VFA) absorption rate, expression of genes involved in VFA metabolism and intracellular $\mathrm{pH}$ regulation in rumen epithelial cells, and in situ carbohydrate digestibility in the rumen. We fed 14 ruminally cannulated mid-lactating dairy cows $(119 \pm 47.2 \mathrm{~d}$ in milk; body weight $640 \pm 47.9 \mathrm{~kg}$ ) a high-grain diet consisting of $30 \%$ forage ad libitum, with an 18-d diet adaptation and a 7-d sample and data collection period. Eight cows with the lowest acidosis index [area below pH 5.8 normalized for dry matter intake (DMI); 0.10 $\pm 0.16 \mathrm{pH} \times \mathrm{min} / \mathrm{kg}$ of $\mathrm{DMI}]$ and 5 with the highest acidosis index $(3.72 \pm 0.19 \mathrm{pH} \times \min / \mathrm{kg}$ of DMI $)$ were classified as animals with lower risk (LS) and higher risk (HS) of SARA, respectively. Minimum (5.75 vs. $5.33)$ and mean rumen $\mathrm{pH}$ (6.33 vs. 5.98) were higher for LS than for HS cows. In addition, the duration and area of rumen $\mathrm{pH}$ below 5.8 was lower in LS cows (24.9 vs. $481 \mathrm{~min} / \mathrm{d} ; 2.94$ vs. $102 \mathrm{pH} \times \mathrm{min} / \mathrm{d}$ ). Although DMI, milk yield, and milk component yields did not differ, milk fat concentration tended to be higher for LS cows than for HS cows (3.36 vs. 2.93\%). However, we observed no difference in VFA absorption rate between LS and HS cows. In situ starch and neutral detergent fiber digestibility were not different between LS and HS cows, but the relative mRNA abundance of lanosterol synthase $(L S S)$ was higher for LS cows than for HS cows. In addition, the mRNA abundance of hydroxy3-methylglutaryl-CoA synthase 1 (HMGCS1) tended to be higher for LS cows than for HS cows. These results suggested that VFA absorption rate might not explain the difference in rumen $\mathrm{pH}$ between LS and HS cows in the current study, even though expression of some genes
\end{abstract}

Received June 6, 2016.

Accepted August 8, 2016.

${ }^{1}$ Corresponding author: masahito.oba@ualberta.ca related to VFA metabolism in rumen epithelium may be associated with variation in the risk of SARA among lactating cows. This variation in the risk of SARA may not be attributed to differences in the capacity of rumen microbes to ferment carbohydrates, because in situ carbohydrate digestibility in the rumen was not different between cows with higher and lower risk of SARA. Key words: rumen acidosis, volatile fatty acid absorption and metabolism, gene expression, in situ rumen digestibility

\section{INTRODUCTION}

Highly fermentable diets are often fed to highproducing lactating cows to increase milk production. However, excessively fermentable diets can increase the risk of SARA. Although the NRC (2001) recommends maximum NFC and minimum NDF levels (\% of DM) to decrease the occurrence of SARA, some cows may still develop it. Previous studies on primiparous dry cows (Penner et al., 2007), beef steers (Brown et al., 2000; Schlau et al., 2012), sheep (Penner et al., 2009a), and lactating dairy cows (Gao and Oba, 2014) have suggested that variation exists in the severity of SARA among animals even when they are fed the same diet. The reasons for this variation are not fully understood.

Rumen $\mathrm{pH}$ is determined by the difference between acid production in the rumen and acid removal from the rumen (Allen, 1997). Acid removal has 3 primary pathways: absorption by rumen epithelium, neutralization by buffers, and passage from the rumen to the lower parts of the digestive tract (Allen, 1997). Variations in risk for SARA among ruminants could be related to at least 1 of these factors (Penner et al. 2009a). Absorption of VFA contributes to approximately $53 \%$ of the total proton removal from the rumen (Allen, 1997), and Penner et al. (2009a) found that in vitro absorption rates of acetate and butyrate by rumen epithelial tissue were higher for sheep at low risk of SARA than for those at high risk, suggesting that differences in VFA absorption rate might be related to variations in the severity of SARA in vivo. We hypothesized that lactat- 
ing dairy cows with lower risk of SARA would have a faster VFA absorption rate than cows with higher risk of SARA.

Besides VFA and proton transportation, the process of VFA absorption involves the exchange of other ions such as $\mathrm{Na}^{+}$and $\mathrm{HCO}_{3}{ }^{-}$, and the metabolism of VFA in epithelial tissue, which can regulate intracellular $\mathrm{pH}$ and VFA absorption (Aschenbach et al., 2011; Penner et al., 2011). Investigation is needed to better understand the relationship between variations in the severity of SARA among cows and the expression of genes associated with ion exchanges, intracellular $\mathrm{pH}$ regulation, and VFA metabolism in rumen epithelial tissue.

Acid production from OM fermentation is another major factor that affects rumen pH. Chen et al. (2012) found that steers with a lower risk of SARA had lower bacterial density from rumen digesta than steers with a higher risk, possibly indicating that less VFA are produced in the rumen of lower-risk steers. Differences in acid production from OM fermentation in the rumen may also be related to variations in the severity of SARA among lactating cows, and we hypothesized that cows with a higher risk of SARA would have greater in situ carbohydrate digestibility in the rumen than cows with a lower risk of SARA.

The objective of this study was to examine whether lactating dairy cows with a higher or lower risk of SARA have differences in VFA absorption rate, expression of genes involved in VFA metabolism and intracellular $\mathrm{pH}$ regulation in rumen epithelial cells, and in situ carbohydrate digestibility in the rumen.

\section{MATERIALS AND METHODS}

The experiment was conducted at the Dairy Research and Technology Center of University of Alberta (Edmonton, AB, Canada), and performed in accordance with the guidelines of the Canadian Council of Animal Care (Ottawa, ON, Canada). All experimental procedures were preapproved by the Animal Care and Use Committee of the University of Alberta.

\section{Animals, Diets, and Experimental Design}

Fourteen multiparous ruminally cannulated mid-lactating Holstein cows (DIM $119 \pm 47.2$; BW $640 \pm 47.9$ $\mathrm{kg}$; mean $\pm \mathrm{SD}$ ) were used in this study. Cows were fed a high-grain diet containing 30\% forage and $70 \%$ concentrate mix (Table 1) ad libitum for $25 \mathrm{~d}$, with an 18-d diet adaptation period and a 7-d data and sample collection period. Cows were housed individually in tie stalls, bedded with wood shavings, and had free access to water. The experimental diet was fed as a TMR to cows individually once daily at $0800 \mathrm{~h}$, and was offered at 105 to $110 \%$ of actual feed intake from the previous day. The amounts of feed offered and refused were recorded daily throughout the study, and samples of feed ingredients were collected daily during the sample collection period. Daily samples of each feed ingredient were composited into 1 sample, and then dried in a forced-air oven (Yamato Scientific America Inc., Santa Clara, CA) for $48 \mathrm{~h}$ at $55^{\circ} \mathrm{C}$ to determine DM concentrations. Dried samples were analyzed for NDF (Van Soest et al., 1991, method A), starch (Hall, 2009), fat (AOAC International, 2006; method 2003.05), and CP (AOAC International, 2000; method 990.03) by Cumberland Valley Analytical Services (Hagerstown, MD). The DM concentration of barley silage was measured twice weekly, also by drying samples in a forced-air oven for $48 \mathrm{~h}$ at $55^{\circ} \mathrm{C}$, and as-fed proportions of feed ingredients were adjusted if necessary. Cows were weighed after the morning milking on 2 consecutive days immediately before the start of the experiment. Cows were milked twice daily at 0400 and $1500 \mathrm{~h}$.

\section{Rumen $\mathrm{pH}$ and Rumen Fermentation}

The $\mathrm{pH}$ measurement system developed by Penner et al. (2006) was used to measure rumen $\mathrm{pH}$ in the ventral sac every $30 \mathrm{~s}$ continuously for $72 \mathrm{~h}$ (d 19-21). Minimum, mean, and maximum $\mathrm{pH}$ were determined each day for each cow and averaged over a 3-d period. Daily duration and area below $\mathrm{pH} 5.8$ were also calculated each day for each cow and averaged over a 3 -d period. DMI was recorded each day for each cow on d 19, 20, and 21, and averaged over a 72-h period. Acidosis index (area under pH 5.8 divided by DMI; Penner et al.,

Table 1. Ingredient and nutrient composition of the experimental diet

\begin{tabular}{lc}
\hline Item & \% of DM \\
\hline Ingredient & \\
Barley silage & 30.0 \\
Barley grain, rolled & 25.5 \\
Corn grain, rolled & 18.9 \\
Canola meal & 14.5 \\
Corn gluten meal & 4.70 \\
Beet pulp & 2.94 \\
Mineral and vitamin mix ${ }^{1}$ & 2.60 \\
Vegetable oil & 0.90 \\
Nutrient composition & \\
DM & 54.6 \\
CP & 16.9 \\
NDF & 26.8 \\
Starch & 31.8 \\
Ether extract & 4.10 \\
NFC & 47.5 \\
Forage NDF & 13.9
\end{tabular}

${ }^{1}$ Contained $15.4 \% \mathrm{Ca}, 2.83 \% \mathrm{P}, 12.4 \% \mathrm{Na}, 25.0 \% \mathrm{Cl}, 5.53 \% \mathrm{Mg}, 0.28 \%$ $\mathrm{S}, 6.43 \% \mathrm{~K}, 3,274 \mathrm{mg} / \mathrm{kg} \mathrm{Fe}, 617 \mathrm{mg} / \mathrm{kg} \mathrm{Cu}, 1,160 \mathrm{mg} / \mathrm{kg} \mathrm{Mn}, 13.9$ $\mathrm{mg} / \mathrm{kg} \mathrm{Co}, 938 \mathrm{mg} / \mathrm{kg} \mathrm{Zn}, 9.23 \mathrm{mg} / \mathrm{kg} \mathrm{Se}, 30.3 \mathrm{mg} / \mathrm{kg} \mathrm{I}, 473 \mathrm{kIU} / \mathrm{kg}$ vitamin A, $48.0 \mathrm{kIU} / \mathrm{kg}$ vitamin $\mathrm{D}, 1,548 \mathrm{IU} / \mathrm{kg}$ vitamin $\mathrm{E}$. 
2009b) was calculated to evaluate the severity of SARA normalized for DMI. Values of mean $\pm 0.5 \times \mathrm{SD}$ of the acidosis index were used as thresholds to identify groups of extreme animals.

Rumen fluid samples were collected every $9 \mathrm{~h}$ over a 72-h period on d 19, 20, and $21(0500,1400$, and 2300 $\mathrm{h}$ on d 19; 0800 and $1700 \mathrm{~h}$ on d 20; and 0200, 1100, and $2000 \mathrm{~h}$ on d 21). Samples were collected in equal proportions from the cranial, ventral, and caudal sacs, and combined to form 1 sample. Samples were then strained through a perforated screen (Peetex; Sefar Canada Inc., Scarborough, ON, Canada; pore size 355 $\mu \mathrm{m})$. Immediately after collection, rumen fluid samples were centrifuged at $3,000 \times g$ at $4^{\circ} \mathrm{C}$ for $20 \mathrm{~min}$, and the supernatants were stored at $-20^{\circ} \mathrm{C}$ until analysis. Samples were composited to yield 1 sample per cow for further analysis.

Gas chromatography was used to analyze VFA profile for rumen fluid samples according to the method described by Khorasani et al. (1996). In addition, rumen ammonia-N concentration was determined as described by Fawcett and Scott (1960).

\section{Blood Collection}

Blood samples were collected every $18 \mathrm{~h}$ on d 19-21 from the coccygeal vessels into tubes containing sodium heparin (Fisher Scientific Company, Nepean, ON, Canada). Immediately following collection, plasma was harvested by centrifuging blood samples at $3,000 \times$ $g$ at $4^{\circ} \mathrm{C}$ for $20 \mathrm{~min}$. Plasma samples were stored at $-20^{\circ} \mathrm{C}$ until analysis. Samples were composited to yield 1 sample per cow for further analysis.

Plasma samples were analyzed for glucose, BHB, free fatty acids, and insulin concentrations. Plasma glucose concentration was measured using a glucose oxidase/ peroxidase enzyme (Sigma, St. Louis, MO) and dianisidine dihydrochloride (Sigma) procedure followed by determination of absorbance at a wavelength of 450 $\mathrm{nm}$. Plasma BHB concentration was measured by the enzymatic oxidation of BHB to acetoacetate using 3-hydroxybutyrate dehydrogenase (Roche, Mississauga, ON, Canada), and the reduction of $\mathrm{NAD}^{+}$to $\mathrm{NADH}$ was measured by a plate reader at a wavelength of 340 $\mathrm{nm}$. We used commercial kits to measure concentrations of plasma free fatty acids (Wako Chemicals USA Inc., Richmond, VA) and insulin (Coat-a-Count kit; Diagnostic Products Corp., Los Angeles, CA).

\section{Milk Composition}

Milk samples were collected from morning and evening milkings on d 19, 20, and 21 of the study.
Samples were analyzed for milk fat, CP, lactose, and MUN using mid-infrared spectroscopy (AOAC International, 2002; method 972.16; MilkoScan FTIR 6000; Foss North America, Brampton, ON, Canada) at the Alberta Central Milk Testing Laboratory (Edmonton, AB, Canada). Milk yield and milk composition data from both morning and evening milkings were used to calculate daily milk composition, and daily data were averaged over $3 \mathrm{~d}$ to yield 1 value per cow.

\section{In Situ Starch and NDF Digestibility}

Samples of feed ingredients (barley silage and concentrate mix) were collected and dried at $55^{\circ} \mathrm{C}$ for 48 $\mathrm{h}$ in a forced-air oven (V-31 STD, Style II, Despatch Industries Inc., Nashua, Mississauga, ON, Canada). Samples were ground through a $1 \mathrm{~mm}$ screen using a Wiley mill (Thomas Wiley, Philadelphia, PA). After grinding, they were mixed according to the DM proportion of TMR (30\% barley silage and $70 \%$ concentrate mix). Bags were prepared so that $2 \mathrm{~g}$ of the mixed sample was placed in 1 nitrogen-free polyester bag ( 5 $\times 10 \mathrm{~cm}$, pore size $50 \mu \mathrm{m}$; R510, Ankom Technology, Macedon, NY). Ten replicate bags ( 5 for starch and 5 for NDF digestibility) were placed in the rumen of each cow via the rumen cannula on d 22. Five bags were removed from the rumen after $7 \mathrm{~h}$ of incubation, and the other 5 bags were removed after $30 \mathrm{~h}$ of incubation. Bags were washed with cold water, and then placed in the forced-air oven for $48 \mathrm{~h}$ at $55^{\circ} \mathrm{C}$ to analyze DM concentrations. Samples collected after $7 \mathrm{~h}$ of incubation were analyzed for starch concentration (Hall, 2009), and samples collected after $30 \mathrm{~h}$ incubation were analyzed for NDF concentration (Van Soest et al., 1991, method A) by Cumberland Valley Analytical Services. Mixed feed ingredient samples before incubation were also analyzed for both starch and NDF concentration by Cumberland Valley Analytical Services. The 7-h starch and 30-h NDF digestibility were calculated as (1 - amount of starch or NDF remaining after rumen incubation / amount of starch or NDF before rumen incubation) $\times 100$, respectively.

\section{Rumen VFA Absorption}

Rumen VFA absorption rate was determined on $\mathrm{d}$ 24 according to the method described by Penner et al. (2009b). Cobalt-EDTA was used as a marker of fluid passage (Udén et al., 1980), and $n$-valeric acid was used as an indicator of VFA clearance (absorption and passage) from the rumen (Resende Júnior et al., 2006). At $4 \mathrm{~h}$ after feeding, $2.5 \mathrm{~L}$ of solution containing $125 \mathrm{~g}$ of Co-EDTA buffered to pH 6.2 with $\mathrm{NaOH}$ and $300 \mathrm{~g}$ 
of $n$-valeric acid (VWR International, Edmonton, AB, Canada) was dosed into the rumen for each cow. The solution was mixed thoroughly with the rumen contents by hand. Immediately before the marker dose, an initial rumen sample was collected (time 0). Subsequent rumen fluid samples were collected at 30,60, 120, 180, 360, 720, and 1,080 min after the dose. Valeric acid concentration was determined for the individual rumen fluid samples as described above for analyzing VFA profile. Co concentration was determined for each sample using atomic absorption (AA240FS; Varian, Palo Alto, CA).

The concentration of Co at time 0 was used as the baseline to correct concentrations measured at other time points (i.e., 30, 60, 120, 180, 360, 720, and 1,080 min relative to dosing). Because markers were dosed at $4 \mathrm{~h}$ after feeding, the concentration of $n$-valeric acid was not necessarily the lowest at time 0 . Therefore, instead of using the concentration at time 0 , we used the lowest concentration as the baseline concentration of $n$-valeric acid to correct concentrations measured at other time points. As described by Resende Júnior et al. (2006), the exponential decay rate of rumen $n$-valeric acid concentration is the VFA clearance rate, and the exponential decay rate of ruminal Co concentration is the VFA passage rate. We then calculated the exponential decay rate for the ratio of rumen $n$-valeric acid and Co concentration to determine the VFA absorption rate, using the nonlinear model procedure of JMP (version 11.0; SAS Institute Inc., Cary, NC) and the equation $\mathrm{Y}_{\mathrm{t}}=\mathrm{Y}_{0} \times \mathrm{e}^{-\mathrm{kt}}$, where $\mathrm{Y}_{\mathrm{t}}=$ concentration at a given time, $\mathrm{Y}_{0}=$ baseline concentration, $\mathrm{k}=$ fractional rate of absorption, and $\mathrm{t}=$ sampling time, $\mathrm{h}$.

\section{Ruminal Papillae Collection}

Approximately 30 ruminal papillae were biopsied from the ventral sac of the rumen $3 \mathrm{~h}$ after feeding on d 24 from each cow. The papillae were rinsed with phosphate-buffered saline ( $\mathrm{pH} 7.4$ ), snap-frozen in liquid nitrogen, and stored at $-80^{\circ} \mathrm{C}$ in RNA-Later solution (Ambion, Inc., Foster City, CA) until analysis.

\section{RNA Extraction and Reverse Transcription}

Total RNA was extracted from the ruminal papillae with Trizol reagent (Life Technologies, Burlington, ON, Canada) as described by Chomczynski and Sacchi (1987). Then, RNA concentration was determined using a spectrophotometer (NanoDrop 2000 Spectrophotometer; NanoDrop Technologies, Wilmington, DE). The quality and integrity of the total RNA extracted were verified by TapeStation (Agilent Technologies, Wald- bronn, Germany), and the value of the RNA integrity number was higher than 8.2 for all samples.

RNA was treated with DNase (Qiagen, Valencia, CA) and then equal amounts of RNA $(1 \mu \mathrm{g})$ were reversetranscribed by MultiScribe reverse transcription (Life Technologies, Carlsbad, CA) and random primers (Life Technologies).

\section{Real-Time Quantitative PCR}

Real-time PCR was performed by 2 methods in this study. First, a batch of target genes was analyzed using Taqman kits, because these target genes had been evaluated in previous studies in our laboratory using these kits (Penner et al., 2009b; Schlau et al., 2012), so they were available for these target genes. Later, a second batch of target genes was selected for real-time PCR analysis. Most of these genes had been evaluated in previous studies using Fast SYBR Green kits (Steele et al., 2011; Chen et al., 2012; Malmuthuge et al., 2013; Yan et al., 2014). Because Fast SYBR Green kits are less expensive than Taqman kits, they were used and evaluated for the second batch of target genes.

Real-time PCR was performed as described previously (Laarman et al., 2012) using Taqman Fast Universal Master Mix (Life Technologies, Carlsbad, CA) with the StepOne Plus Real-Time PCR System (Life Technologies) for the target genes monocarboxylate cotransporter, isoform 1 (MCT1), downregulated in adenoma $(D R A)$, putative anion transporter, isoform 1 (PAT1), sodium hydrogen exchanger, isoforms 1, 2, and 3 (NHE1, NHE2, NHE3, respectively), and sodium/potassium ATPase pump, a 1 (ATP1), which are involved in VFA absorption and intracellular $\mathrm{pH}$ regulation; and target genes 3-hydroxy-3-methylglutaryl-CoA synthase 1 and 2 (HMGCS-1, HMGCS-2), 3-hydroxy-3-methylglutaryl-CoA lyase $(H M G C L)$, and $\beta$-hydroxybutyrate dehydrogenase, isoform 1 and 2 (BDH1, BDH2), which are involved in VFA metabolism and ketogenesis. Primers and probes (Table 2) were used as described previously (Penner et al., 2009b; Schlau et al., 2012). The primers' efficiency was determined using a standard curve method (with at least 4 serial dilutions) in a pool of all samples. All samples were analyzed on 1 plate per gene in triplicate.

Real-time PCR was performed with the StepOnePlus Real-Time PCR System (Life Technologies) using Fast SYBR Green Master Mix (Applied Biosystems, Foster City, CA) according to the manufacturer's instructions for target genes monocarboxylate cotransporter, isoform 4 (MCT4), vacuolar $\mathrm{H}^{+}$ATPase subunit $\mathrm{B}\left(v H^{+}\right.$ATPase), anion exchanger 2 (AE2), and carbonic anhydrase 2 (CA2), which are involved in 
VFA absorption and intracellular $\mathrm{pH}$ regulation; target genes acyl-CoA synthetase short-chain family member 1 (Acyl-CoAs), acetyl-CoA synthetase 2 (Acetyl-CoAs), and acetyl-CoA acyltransferase 1 (ACAA1), which are involved in VFA metabolism and ketogenesis; target genes acetoacetyl-CoA thiolase 2 (ACAT2), 3-hydroxy3-methylglutaryl-CoA reductase $(H M G C R)$, farnesyl diphosphate synthase (FDPS), sterol regulatory element-binding protein 1 and 2 (SREBP1,SREBP2), and lanosterol synthase $(L S S)$, which are involved in cholesterol synthesis; target genes toll-like receptor 2 and 4 (TLR2, TLR4), claudin 1 (CLDN1), junctional adhesion molecule 2 (JAM2), occludin $(O C L N)$, and zonula occluden 1 (ZO1), which are involved in barrier function and tight junction. The primers for MCT4, CA2, JAM2, and ZO1 (Table 2) were designed using Primer Express v.3.0 (Applied Biosystems, Foster City, CA) and analyzed by BLAST (http://blast.ncbi.nlm. nih.gov/Blast.cgi) to verify primer specificity. Other primers were used as described previously (Penner et al., 2009b; Steele et al., 2011; Chen et al., 2012; Schlau et al., 2012; Malmuthuge et al., 2013; Yan et al., 2014). The primers' efficiency was determined using standard curve method (with at least 4 serial dilutions) in a pool of all samples. The program was 40 cycles of $3 \mathrm{~s}$ at $95^{\circ} \mathrm{C}$ and $30 \mathrm{~s}$ at $60^{\circ} \mathrm{C}$. Melting curve analyses were performed for each qPCR sample at the end of each run to ensure the specificity of the amplification. All investigated PCR products showed a single melting peak. All samples were analyzed on 1 plate per gene in triplicate.

The mRNA abundance of target genes was evaluated using the comparative cycle threshold $(\mathbf{C t})$ method, and then normalized using the geometric mean of 3 housekeeping genes, ribosomal protein large, $\mathrm{P} 0$ ( $R P L P 0)$, $\beta$-actin $(A C T B)$, and glyceraldehyde-3-phosphate dehydrogenase $(G A D P H)$, as described previously (Vandesompele et al., 2002; Laarman et al., 2012; Salehi et al., 2016). Briefly, samples from all 14 cows were analyzed on the same plate for 1 gene. For each sample, the Ct value of the gene was calculated, and it was subtracted from the minimum $\mathrm{Ct}$ among all 14 samples to obtain a $\Delta \mathrm{Ct}$ value for the gene. Then, the relative abundance of mRNA for the gene was calculated for each sample by using the formula $\mathrm{Q}=$ amplification efficiency ${ }^{\Delta \mathrm{Ct}}$. The normalized mRNA abundance for the gene was calculated for each sample by using the formula: $Q_{n}$ $=\mathrm{Q} / \mathrm{NF}$, where NF is the normalization factor, calculated as the geometric average of the $\mathrm{Q}$ values for RPLP0, ACTB, and GAPDH for each sample. The $\mathrm{Q}_{\mathrm{n}}$ value of the gene for each cow was used to evaluate for differences in the relative abundance of mRNA between cows with higher and lower risk of SARA.

\section{Statistical Analysis}

All response variables were evaluated using the fit $\mathrm{Y}$ by $\mathrm{X}$ procedure of JMP (version 11.0; SAS Institute Inc., Cary, NC) to compare the group effect according to the following model:

$$
\mathrm{Y}_{\mathrm{i}}=\mu+\mathrm{G}_{\mathrm{i}}+\mathrm{e}_{\mathrm{i}}
$$

where $\mathrm{Y}_{\mathrm{i}}$ is the dependent variable, $\mu$ is overall mean, $\mathrm{G}_{\mathrm{i}}$ is fixed effect of group, and $\mathrm{e}_{\mathrm{i}}$ is the residual. Relationships between the mRNA abundance of genes and minimum ruminal $\mathrm{pH}$ were analyzed using the fit line procedure in JMP. Significance was declared at $P<$ 0.05 and tendency was declared at $0.05<P<0.10$.

\section{RESULTS}

Among all cows, minimum rumen $\mathrm{pH}$, mean rumen $\mathrm{pH}$, duration, and area $\mathrm{pH}$ below 5.8 ranged from 5.13 to $6.03,5.90$ to $6.45,0.17$ to $633 \mathrm{~min} / \mathrm{d}$, and from 0.0 to $111 \mathrm{pH} \times \mathrm{min} / \mathrm{d}$, respectively. The acidosis index ranged from 0.0 to $4.35 \mathrm{pH} \times \mathrm{min} / \mathrm{kg}$ of DMI. The acidosis index of 8 cows was lower than the threshold of mean $-0.5 \times \mathrm{SD}$, and the acidosis index of 5 cows was higher than the value of mean $+0.5 \times \mathrm{SD}$; they were categorized as cows with lower SARA risk (LS) or higher SARA risk (HS), respectively. The acidosis index of 1 cow was between the value of mean $\pm 0.5 \times$ $\mathrm{SD}$; data collected from this cow were not used when comparing the group effect.

\section{Rumen pH, VFA Profile, and VFA Absorption Rate}

We observed no differences in BW or DMI between LS and HS cows $(P>0.10$; Table 3$)$. However, the minimum (5.75 vs. $5.33 ; P<0.01)$ and mean ruminal $\mathrm{pH}(6.33$ vs. $5.98 ; P<0.01)$ were higher for LS cows than for HS cows; maximum $\mathrm{pH}$ values were not different between groups. The duration (24.9 vs. $481 \mathrm{~min} / \mathrm{d}$; $P<0.01)$ and area $(2.94$ vs. $102 \mathrm{pH} \times \min / \mathrm{d} ; P<$ $0.01)$ that $\mathrm{pH}$ was below 5.8 were lower in LS cows. The acidosis index was lower in LS cows $(0.10$ vs. $3.72 \mathrm{pH}$ $\times \mathrm{min} / \mathrm{kg}$ DMI; $P<0.01$ ). Total VFA concentration, VFA profiles, concentration of rumen $\mathrm{NH}_{3}-\mathrm{N}, \mathrm{VFA}$ absorption rate, and liquid passage rate were not different between groups $(P>0.10$; Table 4$)$.

\section{In Situ Starch and NDF Digestibility}

In situ 7-h starch and 30-h NDF digestibility were not different between LS and HS cows $(P>0.10$; Table $4)$. 
Table 2. Gene names, primer, and probe (for Taqman) sequences for real-time quantitative PCR analysis (qPCR)

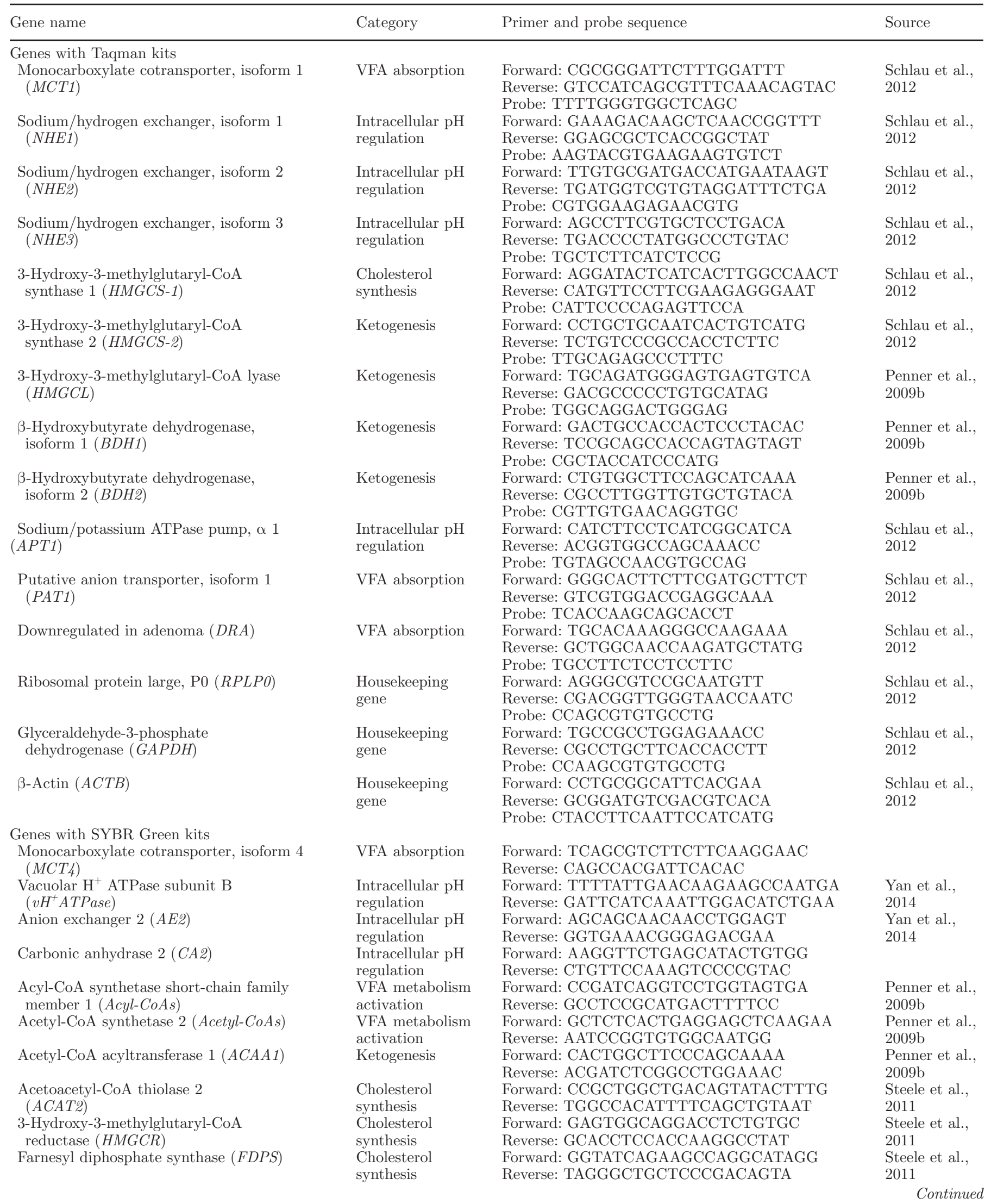


Table 2 (Continued). Gene names, primer, and probe (for Taqman) sequences for real-time quantitative PCR analysis (qPCR)

\begin{tabular}{|c|c|c|c|}
\hline Gene name & Category & Primer and probe sequence & Source \\
\hline Sterol regulatory element-binding protein 2 & Cholesterol & Forward: CTGGCTCCAGGGAGATGAC & Steele et al., \\
\hline Lanosterol synthase $(L S S)$ & $\begin{array}{l}\text { Cholesterol } \\
\text { synthesis }\end{array}$ & $\begin{array}{l}\text { Forward: TGCAGGCGCTGAAGACTTT } \\
\text { Reverse: GCTCAAGGGTCTCCCTGATCT }\end{array}$ & $\begin{array}{l}\text { Steele et al., } \\
2011\end{array}$ \\
\hline Toll-like receptor 2 (TLR2) & Barrier function & $\begin{array}{l}\text { Forward: CTGTGTGCGTCTTCCTCAGA } \\
\text { Reverse: TCAGGGAGCAGAGTAACCAGA }\end{array}$ & $\begin{array}{l}\text { Chen et al., } \\
2012\end{array}$ \\
\hline Claudin $1(C L D N 1)$ & Tight junction & $\begin{array}{l}\text { Forward: GCGCTGCCCCAGTGGAAAGT } \\
\text { Reverse: GGATCTGCCCGGTGCTCTGC }\end{array}$ & $\begin{array}{l}\text { Malmuthuge } \\
\text { et al., } 2013\end{array}$ \\
\hline Junctional adhesion molecule 2 (JAM2) & Tight junction & $\begin{array}{l}\text { Forward: CCCCATCGGAACAAGGTCAA } \\
\text { Reverse: GACATCGCAGCTCTACCACA }\end{array}$ & \\
\hline Occludin $(O C L N)$ & Tight junction & $\begin{array}{l}\text { Forward: ACGCAGGAAGTGCCTTTGGTAGC } \\
\text { Reverse: GCAGCCATGGCCAGCAGGAA }\end{array}$ & $\begin{array}{l}\text { Malmuthuge } \\
\text { et al., } 2013\end{array}$ \\
\hline$\beta$-Actin $(A C T B)$ & $\begin{array}{l}\text { Housekeeping } \\
\text { gene }\end{array}$ & $\begin{array}{l}\text { Forward: CCTGCGGCATTCACGAA } \\
\text { Reverse: GCGGATGTCGACGTCACA }\end{array}$ & $\begin{array}{l}\text { Schlau et al., } \\
2012\end{array}$ \\
\hline
\end{tabular}

\section{Milk Production}

We observed no differences in milk yield or milk component yields between LS and HS cows $(P>0.10$; Table 5). Concentrations of milk protein, lactose, and MUN did not differ between the groups. However, concentrations of milk fat tended to be higher for LS cows than for HS cows (3.36 vs. 2.93\%; $P=0.07)$.

\section{Plasma Metabolites and Hormones}

Plasma glucose, BHB, free fatty acids, and insulin concentrations were not different between LS and HS cows $(P>0.10$; Table 6$)$.

\section{Rumen Epithelium Gene Expression}

The relative mRNA abundance of genes associated with VFA absorption and intracellular $\mathrm{pH}$ regulation were not different between LS and HS cows $(P>0.10$; Table 7). However, the relative mRNA abundance of NHE1 tended to be positively correlated with minimum rumen $\mathrm{pH}(\mathrm{r}=0.47, P=0.08$; Figure 1$)$. Gene-encoding LSS had higher mRNA abundance for LS cows than for HS cows $(P=0.03)$. In addition, the mRNA abundance of HMGCS1 tended to be higher for LS cows than for HS cows $(P=0.08)$. The relative mRNA abundance of the other genes associated with epithelial cell VFA metabolism was not different between LS and HS cows

Table 3. Comparison of BW, DMI, and pH measurements between LS and HS cows ${ }^{1}$

\begin{tabular}{|c|c|c|c|c|c|}
\hline \multirow[b]{2}{*}{ Variable } & \multicolumn{2}{|c|}{$\mathrm{LS}(\mathrm{n}=8)$} & \multicolumn{2}{|c|}{$\mathrm{HS}(\mathrm{n}=5)$} & \multirow[b]{2}{*}{$P$-value } \\
\hline & LSM & $\mathrm{SE}$ & LSM & $\mathrm{SE}$ & \\
\hline $\mathrm{BW}, \mathrm{kg}$ & 658 & 16.2 & 612 & 20.5 & 0.11 \\
\hline DMI, $\mathrm{kg}$ & 29.2 & 1.18 & 28.1 & 1.50 & 0.56 \\
\hline \multicolumn{6}{|l|}{ Ruminal $\mathrm{pH}$} \\
\hline Nadir & 5.75 & 0.05 & 5.33 & 0.06 & $<0.01$ \\
\hline Mean & 6.33 & 0.03 & 5.98 & 0.04 & $<0.01$ \\
\hline Maximum & 6.90 & 0.04 & 6.81 & 0.05 & 0.20 \\
\hline Duration $\mathrm{pH}<5.8$, min & 24.9 & 20.5 & 481 & 26.0 & $<0.01$ \\
\hline Area $\mathrm{pH}<5.8, \mathrm{pH} \times \min$ & 2.94 & 2.18 & 102 & 2.76 & $<0.01$ \\
\hline Acidosis index, $\mathrm{pH} \times \min / \mathrm{kg}$ of DMI & 0.10 & 0.15 & 3.72 & 0.19 & $<0.01$ \\
\hline
\end{tabular}

${ }^{1} \mathrm{LS}=$ cows identified as having low risk of SARA; HS = cows identified as having high risk of SARA. 
Table 4. Comparison of rumen VFA profile, $\mathrm{NH}_{3}-\mathrm{N}$ concentration, VFA absorption rate, and in situ digestibility between LS and HS cows ${ }^{1}$

\begin{tabular}{|c|c|c|c|c|c|}
\hline \multirow[b]{2}{*}{ Variable } & \multicolumn{2}{|c|}{$\mathrm{LS}(\mathrm{n}=8)$} & \multicolumn{2}{|c|}{ HS $(n=5)$} & \multirow[b]{2}{*}{$P$-value } \\
\hline & LSM & $\mathrm{SE}$ & LSM & $\mathrm{SE}$ & \\
\hline \multicolumn{6}{|l|}{$\overline{\text { VFA profile }}$} \\
\hline Total VFA, m $M$ & 129 & 2.88 & 129 & 3.64 & 0.93 \\
\hline Acetate, mol/100 mol & 63.0 & 1.34 & 64.0 & 1.69 & 0.67 \\
\hline Propionate, mol/100 mol & 19.7 & 0.53 & 20.4 & 0.67 & 0.48 \\
\hline Butyrate, mol/100 mol & 13.5 & 0.99 & 11.9 & 1.25 & 0.32 \\
\hline Acetate:propionate & 3.21 & 0.14 & 3.17 & 0.17 & 0.85 \\
\hline Rumen $\mathrm{NH}_{3}-\mathrm{N}, \mathrm{mg} / \mathrm{dL}$ & 11.2 & 0.84 & 11.8 & 1.06 & 0.69 \\
\hline VFA absorption rate, $\% / \mathrm{h}$ & 29.9 & 2.19 & 30.8 & 2.90 & 0.80 \\
\hline Liquid passage rate, $\% / \mathrm{h}$ & 13.6 & 0.92 & 11.3 & 1.09 & 0.13 \\
\hline 7-h starch digestibility, \% & 74.9 & 1.32 & 73.1 & 1.67 & 0.41 \\
\hline 30-h NDF digestibility, $\%$ & 53.2 & 1.78 & 50.2 & 2.25 & 0.32 \\
\hline
\end{tabular}

${ }^{1} \mathrm{LS}=$ cows identified as having low risk of SARA; HS = cows identified as having high risk of SARA.

$(P>0.10)$, but the mRNA abundance of BDH2 tended to be positively correlated with minimum rumen $\mathrm{pH}(\mathrm{r}$ $=0.50, P=0.07)$. The relative mRNA abundance of genes associated with epithelial barrier function and tight junction were not different between LS and HS cows $(P>0.10)$.

\section{DISCUSSION}

Subacute ruminal acidosis is a metabolic disorder commonly found in high-producing dairy cows. Diet formulation strategies can decrease the incidence of SARA, but it still occurs for some cows in a herd. It has been shown that variation in the severity of SARA exists among late-lactation cows when they are fed the same high-grain diet (Gao and Oba, 2014). In the current study, we also detected variations in rumen $\mathrm{pH}$ and the severity of SARA among mid-lactation cows. The absorption of VFA is a major factor that regulates rumen $\mathrm{pH}$, and it has been suggested that over $50 \%$ of the total protons (largest proportion) in the rumen are removed via VFA absorption through rumen epithelial cells in lactating dairy cows (Allen, 1997). In addition, Schlau et al. (2012) showed that LS steers had lower total rumen VFA concentration and higher expression of the NHE3 gene in ruminal epithelial cells compared with HS steers. The NHE3 gene is located on the apical side of ruminal epithelial cells, which takes up $\mathrm{Na}^{+}$into epithelial cells and exports $\mathrm{H}^{+}$to the rumen (Connor et al., 2010). Higher expression of NHE3 may increase the release of $\mathrm{H}^{+}$to the rumen (Schlau et al., 2012), leading to a decrease in local $\mathrm{pH}$ and increase of the undissociated form of VFA near the epithelial cells; these effects may increase VFA absorption via simple diffusion (Graham et al., 2007; Connor et al., 2010; Schlau et al., 2012). Responses of rumen VFA concentration and expression of the NHE3 gene suggested that higher rumen $\mathrm{pH}$ for LS steers might be partly due to higher VFA absorption rate than for HS steers (Schlau et al., 2012). In the present study, we hypothesized that VFA absorption might be one of the main factors causing the variation in the risk of SARA for lactating dairy cows, but we did not detect a difference in VFA absorption rate between LS and HS cows.

Table 5. Comparison of milk yield and milk composition between LS and HS cows ${ }^{1}$

\begin{tabular}{|c|c|c|c|c|c|}
\hline \multirow[b]{2}{*}{ Variable } & \multicolumn{2}{|c|}{$\mathrm{LS}(\mathrm{n}=8)$} & \multicolumn{2}{|c|}{$\mathrm{HS}(\mathrm{n}=5)$} & \multirow[b]{2}{*}{$P$-value } \\
\hline & LSM & $\mathrm{SE}$ & LSM & $\mathrm{SE}$ & \\
\hline \multicolumn{6}{|l|}{ Yield, $\mathrm{kg} / \mathrm{d}$} \\
\hline Milk & 37.9 & 2.04 & 40.4 & 2.59 & 0.46 \\
\hline Fat & 1.27 & 0.08 & 1.18 & 0.10 & 0.50 \\
\hline $\mathrm{CP}$ & 1.19 & 0.06 & 1.23 & 0.07 & 0.65 \\
\hline Lactose & 1.75 & 0.11 & 1.85 & 0.14 & 0.58 \\
\hline \multicolumn{6}{|c|}{ Milk composition } \\
\hline Fat, $\%$ & 3.36 & 0.14 & 2.93 & 0.17 & 0.07 \\
\hline CP, \% & 3.17 & 0.07 & 3.06 & 0.09 & 0.40 \\
\hline Lactose, \% & 4.60 & 0.06 & 4.57 & 0.08 & 0.77 \\
\hline MUN, mg/dL & 12.9 & 0.58 & 12.2 & 0.74 & 0.49 \\
\hline
\end{tabular}

${ }^{1} \mathrm{LS}=$ cows identified as having low risk of SARA; HS = cows identified as having high risk of SARA. 
Table 6. Comparison of plasma blood metabolite and hormone concentrations between LS and HS cows ${ }^{1}$

\begin{tabular}{|c|c|c|c|c|c|}
\hline \multirow[b]{2}{*}{ Variable } & \multicolumn{2}{|c|}{$\mathrm{LS}(\mathrm{n}=8)$} & \multicolumn{2}{|c|}{$\mathrm{HS}(\mathrm{n}=5)$} & \multirow[b]{2}{*}{$P$-value } \\
\hline & LSM & $\mathrm{SE}$ & LSM & $\mathrm{SE}$ & \\
\hline Glucose, $\mathrm{mg} / \mathrm{dL}$ & 64.1 & 0.79 & 61.9 & 1.00 & 0.12 \\
\hline $\mathrm{BHB}, \mathrm{mg} / \mathrm{dL}$ & 10.3 & 0.84 & 11.3 & 1.07 & 0.48 \\
\hline Free fatty acids, $\mathrm{mEq} / \mathrm{L}$ & 84.0 & 7.95 & 92.1 & 10.1 & 0.54 \\
\hline Insulin, $\mu \mathrm{IU} / \mathrm{mL}$ & 8.57 & 0.57 & 7.66 & 0.72 & 0.34 \\
\hline
\end{tabular}

${ }^{1} \mathrm{LS}=$ cows identified as having low risk of SARA; HS = cows identified as having high risk of SARA.

There are a couple of possible explanations for our observation that the fractional rate of VFA absorption did not differ between LS and HS cows. One is that variation in the risk of SARA among cows was not large enough in the present study - that the LS and HS cows selected were not extreme enough - and differences in VFA absorption rate were not large enough to be detected between LS and HS cows. In a previous study using crossbred beef steers, the acidosis index was $13.5 \mathrm{pH} \times \mathrm{min} / \mathrm{kg}$ of DMI for LS steers, but $61.7 \mathrm{pH}$ $\times \mathrm{min} / \mathrm{kg}$ of DMI for HS steers (Schlau et al., 2012).
In the present study, the acidosis index was $0.10 \mathrm{pH}$ $\times \mathrm{min} / \mathrm{kg}$ of DMI for LS cows and $3.72 \mathrm{pH} \times \mathrm{min} / \mathrm{kg}$ of DMI for HS cows, so differences between the animals selected for the present study were less extreme. Smaller variations in the risk of SARA in the present study might be due to decreased genetic diversity and an increased inbreeding coefficient for Holstein dairy cows. Inbreeding levels have increased over the past decades in the Holstein breed, and it has been shown that the average inbreeding coefficient for Holstein cows was between 6 and $7 \%$ in Canada in 2008 (Stachowicz et al.,

Table 7. Comparison of mRNA abundance of genes involved in intracellular $\mathrm{pH}$ regulation, VFA metabolism, and tight junction between LS and HS cows ${ }^{1}$

\begin{tabular}{|c|c|c|c|c|c|c|}
\hline \multirow[b]{2}{*}{ Gene $^{2}$} & \multicolumn{2}{|c|}{$\mathrm{LS}(\mathrm{n}=8)$} & \multicolumn{2}{|c|}{$\mathrm{HS}(\mathrm{n}=5)$} & \multirow[b]{2}{*}{$P$-value } & \multirow{2}{*}{$\begin{array}{l}\text { Efficiency of } \\
\text { amplification, \% }\end{array}$} \\
\hline & LSM & SE & LSM & SE & & \\
\hline$M C T 1$ & 1.09 & 0.08 & 0.99 & 0.10 & 0.46 & 97.9 \\
\hline NHE 1 & 1.15 & 0.05 & 1.07 & 0.06 & 0.38 & 98.4 \\
\hline NHE2 & 1.07 & 0.03 & 0.99 & 0.04 & 0.18 & 93.0 \\
\hline NHE3 & 0.94 & 0.09 & 0.80 & 0.11 & 0.33 & 101 \\
\hline$H M G C S-1$ & 0.91 & 0.05 & 0.77 & 0.06 & 0.08 & 92.2 \\
\hline$H M G C S-2$ & 1.15 & 0.08 & 1.17 & 0.10 & 0.87 & 95.9 \\
\hline$H M G C L$ & 1.13 & 0.05 & 1.09 & 0.06 & 0.68 & 89.3 \\
\hline$B D H 1$ & 0.99 & 0.06 & 0.99 & 0.08 & 0.93 & 101 \\
\hline BDH2 & 1.19 & 0.05 & 1.10 & 0.06 & 0.25 & 97.7 \\
\hline ATP1 & 1.03 & 0.05 & 0.93 & 0.06 & 0.22 & 97.0 \\
\hline PAT1 & 1.01 & 0.05 & 0.96 & 0.07 & 0.61 & 101 \\
\hline$D R A$ & 0.93 & 0.10 & 0.80 & 0.12 & 0.41 & 98.3 \\
\hline$M C T 4$ & 0.84 & 0.05 & 0.92 & 0.06 & 0.35 & 93.3 \\
\hline$v H^{+}$ATPase & 0.95 & 0.03 & 0.94 & 0.04 & 0.78 & 99.9 \\
\hline AE2 & 0.97 & 0.04 & 1.02 & 0.05 & 0.46 & 94.8 \\
\hline$C A 2$ & 0.84 & 0.06 & 0.88 & 0.07 & 0.70 & 104 \\
\hline Acyl-CoAs & 0.92 & 0.05 & 0.96 & 0.07 & 0.67 & 101 \\
\hline Acetyl-CoAs & 0.95 & 0.05 & 1.03 & 0.07 & 0.35 & 101 \\
\hline$A C A A 1$ & 1.01 & 0.03 & 0.97 & 0.04 & 0.52 & 95.7 \\
\hline ACAT2 & 1.04 & 0.04 & 1.09 & 0.04 & 0.44 & 96.0 \\
\hline$H M G C R$ & 0.93 & 0.03 & 0.86 & 0.04 & 0.29 & 94.9 \\
\hline$F D P S$ & 0.91 & 0.05 & 0.84 & 0.07 & 0.42 & 97.7 \\
\hline$S R E B P 1$ & 0.88 & 0.05 & 0.89 & 0.07 & 0.87 & 96.5 \\
\hline SREBP2 & 0.94 & 0.02 & 0.97 & 0.03 & 0.38 & 97.4 \\
\hline$L S S$ & 0.91 & 0.04 & 0.75 & 0.05 & 0.03 & 95.6 \\
\hline TLR2 & 0.66 & 0.06 & 0.80 & 0.08 & 0.22 & 103 \\
\hline$T L R 4$ & 0.79 & 0.08 & 0.85 & 0.10 & 0.62 & 104 \\
\hline$C L D N 1$ & 0.89 & 0.05 & 0.82 & 0.06 & 0.39 & 96.9 \\
\hline$J A M 2$ & 0.89 & 0.06 & 1.03 & 0.08 & 0.21 & 104 \\
\hline$O C L N$ & 0.99 & 0.04 & 1.01 & 0.05 & 0.76 & 98.3 \\
\hline$Z O 1$ & 1.04 & 0.05 & 1.05 & 0.06 & 0.89 & 95.5 \\
\hline
\end{tabular}

${ }^{1} \mathrm{LS}=$ cows identified as having low risk of SARA; HS = cows identified as having high risk of SARA.

${ }^{2}$ See Table 2 for full list of gene names. 

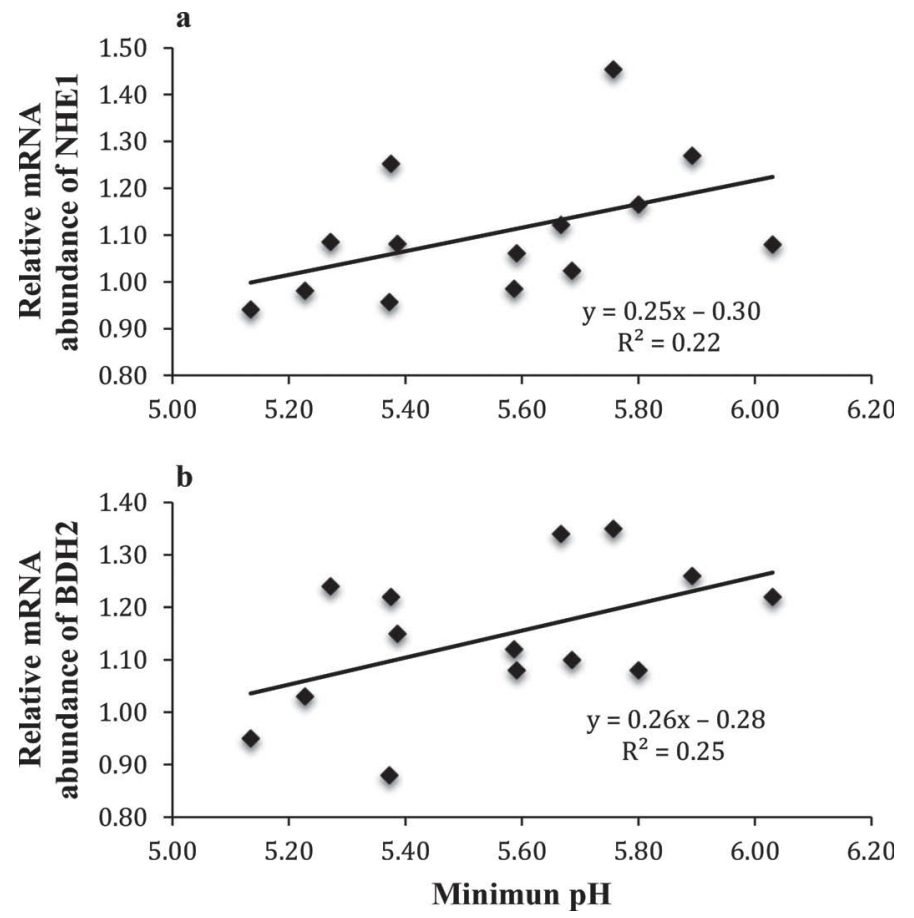

Figure 1. Relationship between minimum rumen $\mathrm{pH}$ with (a) relative mRNA abundance of sodium/hydrogen exchanger, isoform 1 (NHE1; $P=0.08$ ) and $(\mathrm{b})$ relative mRNA abundance of $\beta$-hydroxybutyrate dehydrogenase, isoform $2(B D H 2 ; P=0.07)$.

2011). Increased inbreeding levels could cause significant loss of genetic diversity for Holsteins (Sørensen et al., 2005), and Stachowicz et al. (2011) suggested that about $6.5 \%$ of genetic diversity in Holsteins has been lost since the founder generations. On our research dairy farm, the herd is closed, and artificial insemination is implemented with a limited number of sires. Less genetic variation for Holstein cows used in the present study might explain the smaller variations in the risk of SARA than that of the crossbred steers in the previous study (Schlau et al., 2012).

A second possibility is that the intensity of acidosis challenge in the current study might not have been severe enough to cause different VFA absorption responses between LS and HS cows. In this study, the challenge was feeding cows a TMR with $44.4 \%$ grain on a DM basis. In the beef steer study, Schlau et al. (2012) challenged steers by feeding a diet consisting of $85 \%$ grain on DM basis to induce SARA. The mean rumen $\mathrm{pH}$ in the present study was 6.33 for LS cows and 5.98 for HS cows; in the beef steer study, it was 6.01 for LS steers and 5.51 for HS steers. These findings indicate that the intensity of the challenge to the rumen epithelial tissue might have been less sufficient in the present study than in the beef steer study (Schlau et al., 2012) to explain why no difference was detected in VFA absorption rate between LS and HS cows.

Increasing absorption and metabolism of VFA in rumen epithelial cells has been proposed as a potential mechanism for decreasing the risk of ruminal acidosis (Gäbel et al., 2002). The metabolism of VFA could create a concentration gradient between the cytosol and rumen, which may promote the absorption of VFA (Gäbel et al., 2002; Penner et al., 2011). In this study, we did not detect a significant difference in the fractional rate of VFA absorption between LS and HS cows, but we did find that the mRNA abundance of LSS was higher for LS cows than HS ones, and the mRNA abundance of HMGCS1 tended to be higher for LS cows than for HS cows. Lanosterol synthase is the enzyme catalyzing the synthesis of lanosterol, which is the key intermediate in the biosynthesis of cholesterol (Dempsey, 1974; Huff and Telford, 2005). The enzyme HMGCS1 also catalyzes butyrate metabolism in the cytosol for cholesterol synthesis (Hegardt, 1999; Penner et al., 2011). Cholesterol biosynthesis is an alternative pathway of VFA metabolism in the rumen epithelial cells besides ketogenesis (Steele et al., 2011). Steele et al. (2011) showed that genes involved in cholesterol biosynthesis were upregulated in the rumen epithelial cells during the first week of a high-grain diet challenge, but then downregulated in the third week. High cholesterol concentration in the cell is associated with cellular inflammation, oxidative stress, proliferation, and membrane permeability (Kleemann and Kooistra, 2005; Steele et al., 2011). It was proposed that upregulation of genes related to VFA metabolism during the first week was due to an increased amount of VFA substrate for cholesterol biosynthesis in the rumen epithelial cells during a high-grain diet challenge, which might increase the intracellular cholesterol concentration and cause the possible abnormalities in cholesterol homeostasis and inflammation (Steele et al., 2011). Therefore, genes associated with cholesterol biosynthesis were downregulated from wk 1 to 3 to compensate for the increased intracellular cholesterol concentration and maintain intracellular cholesterol homeostasis (Steele et al., 2011). In the present study, LS cows had a higher mRNA abundance of genes related to cholesterol biosynthesis than HS cows, suggesting that LS cows might have a higher capacity to cope with elevated cholesterol levels in rumen epithelial cells or a higher capacity to clear the cholesterol from rumen epithelial cells to the blood. In addition, ketogenesis is the primary pathway of VFA metabolism in the ruminal epithelial cells (Penner et al., 2011). However, we did not detect significant differences in the mRNA abundance of genes associated with VFA metabolism via ketogenesis pathways between LS 
and HS cows. Consistently, Schlau et al. (2012) did not find differences in the expression of genes related to ketogenesis between LS and HS steers. Still, we found that the mRNA abundance of $B D H 2$ tended to be positively correlated with minimum rumen $\mathrm{pH}$; $\mathrm{BDH} 2$ catalyzes the pathway of cytosolic ketogenesis, and the ketone body could be further used as a precursor for lipid and sterol synthesis (Guo et al., 2006). Together, in this study, variations in the severity of SARA among cows might be partly due to differences in VFA metabolism in rumen epithelial cells. Penner et al. (2009b) also reported negative correlations between the expression of genes associated with VFA metabolism and the severity of SARA for dairy cows. But even though we detected the changes in the expression of genes, protein abundance and activity were not measured in this study, and differences in mRNA abundance do not necessarily mean differences in protein activity.

In the present study, we did not find significant differences in the mRNA abundance of genes related to transportation of ions and VFA, and to intracellular $\mathrm{pH}$ regulation. Also, we observed no significant relationship between VFA absorption rate and expression of these genes in this study (data not shown). Schlau et al. (2012) found that the mRNA abundance of NHE3 in ruminal epithelial cells was greater for LS than for HS beef steers in a previous study. Ruminal papillae samples were collected at 2,4 , and $6 \mathrm{~h}$ after forcefeeding in that study, but samples were biopsied at $3 \mathrm{~h}$ after feeding in the present study. Although the numerical difference in expression of NHE3 between LS and HS steers was highest at the 2-h time point, we observed no significant interaction between group effect and time of sampling for NHE3 gene expression (Schlau, 2012). Therefore, sampling time may not be the key factor for explaining the different responses in NHE3 expression between these 2 studies. As discussed above, genetic variation and the intensity of acidosis challenge may be the possible reasons. In addition, we found a tendency for the relative mRNA abundance of NHE1 to be positively correlated with minimum rumen $\mathrm{pH}$, although we observed no difference between LS and HS cows. However, we observed no relationship between the relative mRNA abundance of NHE1 with mean rumen $\mathrm{pH}$ and acidosis index, indicating that the intensity of the acidosis challenge might not have been severe enough to cause different responses in expression of NHE genes between LS and HS cows.

Rumen $\mathrm{pH}$ is a function of acid production and removal (Allen, 1997). Therefore, acid produced from rumen OM fermentation is another main factor affecting rumen pH. Schlau et al. (2012) suggested that higher rumen $\mathrm{pH}$ for LS steers might be partly due to lower
VFA production. Carbohydrates normally account for approximately 65 to $70 \%$ of DM in the diets for lactating dairy cows (NRC, 2001), and starch and fiber are the main carbohydrate sources. Therefore, we expected that LS cows would have less ruminal fermentation of starch and NDF than HS cows. Substrate, microbes, and ruminal retention time affect the extent of carbohydrate fermentation in the rumen. Measurement of in situ carbohydrate digestibility removes possible confounding factors caused by differences in substrate and retention time in the rumen, and indicates the capacity of microbes to ferment carbohydrates in the rumen. However, we did not detect differences in in situ 7-h starch or 30-h NDF digestibility between LS and HS cows. This lack of difference indicated that the capacity of rumen microbes to ferment carbohydrates might not be related to variations in risk of SARA among cows. But we could not exclude the possibility of differences in VFA production as a factor causing variations in rumen $\mathrm{pH}$, because other factors (such as rumen digesta passage rate) also have an effect on rumen fermentation and VFA production. Previous studies have shown that the passage rate of digesta affects feed degradability (Robinson et al., 1987) and microbial efficiency (Sniffen and Robinson, 1987). Orskow and McDonald (1979) suggested that higher passage rates lead to less degradability. Therefore, it is possible that rumen digesta passage rate was variable among cows, possibly causing the differences in VFA production, even though in situ starch and NDF digestibility was the same between LS and HS cows. Further research on differences in rumen digesta passage rate and net rumen VFA production between LS and HS cows is needed to determine whether the extent of rumen fermentation and VFA production is related to variation in risk of SARA among cows. In addition, as a pathway of proton removal, passage from the rumen is also a factor regulating rumen $\mathrm{pH}$. Allen (1997) suggested that approximately $15 \%$ of total acids were removed from the rumen by passage. In this study, liquid passage rate was not significantly different between LS and HS cows. Therefore, passage from the rumen may not be a factor contributing the variation in the risk of SARA among cows in this study.

\section{CONCLUSIONS}

Variation exists in the risk of developing SARA among lactating dairy cows fed a high-grain diet; however, this variation cannot be attributed to differences in rumen microbial capacity to ferment carbohydrates, because in situ carbohydrate digestibility in the rumen was not different between cows with higher and lower risk of SARA. Although the expression of some genes involved 
in VFA metabolism in rumen epithelium was related to variation in risk of SARA, VFA absorption rate did not explain the difference in rumen $\mathrm{pH}$ between cows with higher and lower risk of SARA in the present study.

\section{ACKNOWLEDGMENTS}

This study was supported by Alberta Milk (Edmonton, AB, Canada) and Natural Sciences and Engineering Research Council of Canada (Ottawa, ON, Canada). The authors thank J. Haisan, S. Espinoza, K. Macmillan, M. Roseboom, and A. Ruiz-Sanchez (University of Alberta, Edmonton, AB, Canada) for their assistance with animal handling and sample collections. The authors also acknowledge L. L. Guan and Y. Chen (University of Alberta) for their assistance with laboratory analysis.

\section{REFERENCES}

Allen, M. S. 1997. Relationship between fermentation acid production in the rumen and the requirement for physically effective fiber. J. Dairy Sci. 80:1447-1462.

AOAC International. 2000. Official Methods of Analysis. 17th ed. AOAC Int., Gaithersburg, MD.

AOAC International. 2002. Official Methods of Analysis. 17th ed. AOAC Int., Gaithersburg, MD.

AOAC International. 2006. Official Methods of Analysis. Crude Fat in Feeds, Cereal Grains, and Forages (2003.05). 18th ed. Tecator, Foss NA, Eden Prairie, MN.

Aschenbach, J. R., G. B. Penner, F. Stumpff, and G. Gäbel. 2011. Ruminant nutrition symposium: Role of fermentation acid absorption in the regulation of ruminal pH. J. Anim. Sci. 89:1092-1107.

Brown, M. S., C. Krehbiel, M. Galyean, M. Remmenga, J. Peters, B. Hibbard, J. Robinson, and W. Moseley. 2000. Evaluation of models of acute and subacute acidosis on dry matter intake, ruminal fermentation, blood chemistry, and endocrine profiles of beef steers. J. Anim. Sci. 78:3155-3168.

Chen, Y., M. Oba, and L. L. Guan. 2012. Variation of bacterial communities and expression of Toll-like receptor genes in the rumen of steers differing in susceptibility to subacute ruminal acidosis. Vet. Microbiol. 159:451-459.

Chomczynski, P., and N. Sacchi. 1987. Single-step method of RNA isolation by acid guanidinium thiocyanate phenol chloroform extraction. Anal. Biochem. 162:156-159.

Connor, E. E., R. W. Li, R. L. Baldwin, and C. Li. 2010. Gene expression in the digestive tissues of ruminants and their relationships with feeding and digestive processes. Animal 4:993-1007.

Dempsey, M. E. 1974. Regulation of steroid biosynthesis. Annu. Rev. Biochem. 43:967-990.

Fawcett, J. K., and J. E. Scott. 1960. A rapid and precise method for the determination of urea. J. Clin. Pathol. 13:156-159.

Gäbel, G., J. R. Aschenbach, and F. Müller. 2002. Transfer of energy substrates across the ruminal epithelium: Implications and limitations. Anim. Health Res. Rev. 3:15-30.

Gao, X., and M. Oba. 2014. Relationship of severity of subacute ruminal acidosis to rumen fermentation, chewing activities, sorting behaviour, and milk production in lactating dairy cows fed a highgrain diet. J. Dairy Sci. 97:3006-3016.

Graham, C., I. Gatherar, I. Haslam, M. Glanville, and N. L. Simmons. 2007. Expression and localization of monocarboxylate transporters and sodium/proton exchangers in bovine rumen epithelium. Am. J. Physiol. Regul. Integr. Comp. Physiol. 292:R977-1007.
Guo, K., P. Lukacik, E. Papagrigoriou, M. Meier, W. H. Lee, J. Adamski, and U. Oppermann. 2006. Characterization of human DHRS6, an orphan short chain dehydrogenase/reductase enzyme: A novel, cytosolic type 2 R-beta-hydroxybutyrate dehydrogenase. J. Biol. Chem. 281:10291-10297.

Hall, M. B. 2009. Analysis of starch, including maltooligosaccharides, in animal feeds: A comparison of methods and a recommended method for AOAC collaborative study. J AOAC Int. 92:42-49.

Hegardt, F. G. 1999. Mitochondrial 3-hydroxy-3-methylglutaryl-CoA synthase: A control enzyme in ketogenesis. Biochem. J. 338:569582.

Huff, M. W., and D. E. Telford. 2005. Lord of the rings - The mechanism for oxidosqualene: Lanosterol cyclase becomes crystal clear. Trends Pharmacol. Sci. 26:335-340.

Khorasani, G. R., E. K. Okine, and J. J. Kennelly. 1996. Forage source alters nutrient supply to the intestine without influencing milk yield. J. Dairy Sci. 79:862-872.

Kleemann, R., and T. Kooistra. 2005. HMG-CoA reductase inhibitors: Effects on chronic subacute inflammation and onset of atherosclerosis induced by dietary cholesterol. Curr. Drug Targets Cardiovasc. Haematol. Disord. 5:441-453.

Laarman, A. H., A. L. Ruiz-Sanchez, T. Sugino, L. L. Guan, and M. Oba. 2012. Effects of feeding a calf starter on molecular adaptations in the ruminal epithelium and liver of Holstein dairy calves. J. Dairy Sci. 95:2585-2594.

Malmuthuge, N., M. Li, L. A. Goonewardene, M. Oba, and L. L. Guan. 2013. Effect of calf starter feeding on gut microbial diversity and expression of genes involved in host immune responses and tight junctions in dairy calves during weaning transition. J. Dairy Sci. 96:3189-3200.

NRC. 2001. Nutrient Requirements of Dairy Cattle. 7th rev. ed. Natl. Acad. Sci., Washington, DC.

Orskow, E. R., and I. McDonald. 1979. The estimation of protein degradability in rumen from incubation measurements weighted according to rate of passage. J. Agric. Sci. 92:499-503.

Penner, G. B., J. R. Aschenbach, G. Gaebel, R. Rackwitz, and M. Oba. 2009a. Epithelial capacity for apical uptake of short chain fatty acids is a key determinant for intraruminal $\mathrm{pH}$ and the susceptibility to subacute ruminal acidosis in sheep. J. Nutr. 139:1714-1720.

Penner, G. B., K. A. Beauchemin, and T. Mutsvangwa. 2006. An evaluation of the accuracy and precision of a stand-alone submersible continuous ruminal $\mathrm{pH}$ measurement system. J. Dairy Sci. $89: 2132-2140$

Penner, G. B., K. A. Beauchemin, and T. Mutsvangwa. 2007. Severity of ruminal acidosis in primiparous Holstein cows during the periparturient period. J. Dairy Sci. 90:365-375.

Penner, G. B., M. A. Steele, J. R. Aschenbach, and B. W. McBride. 2011. Ruminant Nutrition Symposium: Molecular adaptation of ruminal epithelia to highly fermentable diets. J. Anim. Sci. 89:1108-1119.

Penner, G. B., M. Taniguchi, L. L. Guan, K. A. Beauchemin, and M. Oba. 2009b. Effect of dietary forage to concentrate ratio on volatile fatty acid absorption and the expression of genes related to volatile fatty acid absorption and metabolism in ruminal tissue. J. Dairy Sci. 92:2767-2781.

Resende Júnior, J. C., M. N. Pereira, H. Boer, and S. Tamminga. 2006. Comparison of techniques to determine the clearance of ruminal volatile fatty acids. J. Dairy Sci. 89:3096-3106.

Robinson, P. H., S. Tamminga, and A. M. Van Vuuren. 1987. Influence of declining level of feed intake and varying the proportion of starch in the concentrate on rumen ingesta quantity, composition and kinetics of ingesta turnover in dairy cows. Livest. Prod. Sci. $17: 37-62$.

Salehi, R., M. G. Colazo, M. Gobikrushanth, U. Basu, and D. J. Ambrose. 2016. Effects of prepartum oilseed supplements on subclinical endometritis, pro- and anti-inflammatory cytokine transcripts in endometrial cells and postpartum ovarian function in dairy cows. Reprod. Fertil. Dev. /http://dx.doi.org/10.1071/RD15334.

Schlau, N. 2012. Evaluation of factors associated with resistance to sub-acute ruminal acidosis. MS Thesis. University of Alberta, Edmonton, Alberta, Canada. 
Schlau, N., L. L. Guan, and M. Oba. 2012. The relationship between ruminal acidosis resistance and expression of genes involved in regulation of intracellular $\mathrm{pH}$ and butyrate metabolism of ruminal epithelial cells in steers. J. Dairy Sci. 95:5866-5875.

Sniffen, C. J., and P. H. Robinson. 1987. Microbial growth and flow as influenced by dietary manipulations. J. Dairy Sci. 70:425-441.

Sørensen, A. C., M. K. Sørensen, and P. Berg. 2005. Inbreeding in Danish dairy cattle breeds. J. Dairy Sci. 88:1865-1872.

Stachowicz, K., M. Sargolzaei, F. Miglior, and F. S. Schenkel. 2011. Rates of inbreeding and genetic diversity in Canadian Holstein and Jersey cattle. J. Dairy Sci. 94:5160-5175.

Steele, M. A., G. Vandervoort, O. AlZahal, S. E. Hook, J. C. Matthews, and B. W. McBride. 2011. Rumen epithelial adaptation to high-grain diets involves the coordinated regulation of genes involved in cholesterol homeostasis. Physiol. Genomics 43:308-316.
Udén, P., P. E. Colucci, and P. J. Van Soest. 1980. Investigation of chromium, cerium and cobalt as markers in digesta rate of passage studies. J. Sci. Food Agric. 31:625-632.

Van Soest, P. J., J. B. Robertson, and B. A. Lewis. 1991. Methods for dietary fibre, neutral detergent fibre, and nonstarch polysaccharide in relation to animal nutrition. J. Dairy Sci. 74:3583-3597.

Vandesompele, J., K. De Preter, F. Pattyn, B. Poppe, N. Van Roy, A. De Paepe, and F. Speleman. 2002. Accurate normalization of real-time quantitative RT-PCR data by geometric averaging of multiple internal control genes. Genome Biol. 3:RESEARCH0034.

Yan, L., B. Zhang, and Z. Shen. 2014. Dietary modulation of the expression of genes involved in short-chain fatty acid absorption in the rumen epithelium is related to short-chain fatty acid concentration and $\mathrm{pH}$ in the rumen of goats. J. Dairy Sci. 97:5668-5675. 